\title{
CARDIAC GLYCOSIDES, PHENOLIC COMPOUNDS AND ANTIOXIDANT ACTIVITY FROM PLANT CELL SUSPENSION CULTURES OF Thevetia peruviana
}

\section{PRODUCCIÓN DE GLíCOSIDOS CARDIOTÓNICOS, COMPUESTOS FENó́LICOS Y ACTIVIDAD ANTIOXIDANTE EN CULTIVOS DE CÉLULAS VEGETALES EN SUSPENSIÓN DE Thevetia peruviana}

\author{
Juan Pablo Arias $^{1^{*}}$, Karol Zapata ${ }^{2}$, Benjamín Rojano ${ }^{3}$, Mariana Peñuela ${ }^{4}$, Mario Arias $^{5}$
}

\begin{abstract}
${ }^{1}$ Ingeniero Biológico, Magister en Biotecnología y Candidato a Doctor en Biotecnología. Integrante de los Grupos de Investigación Biotecnología Industrial y Bioprocesos adscritos a la Universidad Nacional de Colombia Sede Medellín y la Universidad de Antioquia, respectivamente. Universidad Nacional de Colombia Sede Medellín. Facultad de Ciencias. Calle 59A. No 63-20 Bloque 19A-313 Medellín Colombia; e-mail: jpariase@unal.edu.co * corresponding autor; ${ }^{2}$ Ingeniera Biológica, Magíster en Ciencia y Tecnología de Alimentos y Candidata a Doctora en Biotecnología de la Universidad Nacional de Colombia, sede Medellín.. Universidad Nacional de Colombia Sede Medellín. Facultad de Ciencias. Calle 59A. No 6320 Bloque 19A-211; e-mail: kzapata@unal.edu.co; ${ }^{3}$ Químico, Magister en Ciencia y Tecnología de Alimentos y Doctor en Ciencias Químicas. Profesor titular. Universidad Nacional de Colombia Sede Medellín. Facultad de Ciencias. Calle 59A. No 63-20 Bloque 19A-211; e-mail: brojano@unal.edu.co; ${ }^{4}$ Ingeniera Química, Magister y Doctora en Tecnología de Procesos Químicos y Bioquímicos. Docente Universidad de Antioquia. Facultad de Ingeniería. Calle 70 No. 52 - 21. Bloque 18-405. Medellín, Colombia. mariana.penuela@udea.edu.co; ${ }^{5}$ Ingeniero Químico, Magister en Tecnología de Procesos Químicos y Bioquímicos, Doctor en Ingeniería Química. Docente Universidad Nacional de Colombia Sede Medellín. Facultad de Ciencias. Calle 59A. No 63-20 Bloque 19A-313. Medellín Colombia. E-mail: marioari@unal.edu.co
\end{abstract}

Rev. U.D.C.A Acrt. \& Div. Cient.20(2): 353-362, Julio-Diciembre, 2017

\section{SUMMARY}

Cell suspension cultures of Thevetia peruviana were established under dark for 19 days to investigate kinetic behavior related to biomass, substrate, cardiac glycoside, polyphenols, reactive oxygen species and anti-oxidant activity. The results showed high biomass production (18.80gDW/L) as well as sucrose consumption in 7 days. Preferential glucose over fructose consumption was observed. Intracellular production of cardiac glycosides reached $2.58 \mathrm{mg} \mathrm{DE} / \mathrm{gDW}$ at day 19. Highest extracellular production was reached between day 2 and 7 (6.19mg DE/L). Highest extracellular phenolic content was $80.61 \pm 5.16 \mathrm{mg} \mathrm{GAE} / \mathrm{L}$ at day 7 . Intracellular phenolic content increased to $2.76 \pm 0.14 \mathrm{mg}$ GAE/gFW at day 7 and remained constant until day 19. ROS production at day 7 could be related to sucrose and glucose total consumption. Pearson Product-Moment Correlation Coefficient $(\rho)$ showed that the phenolic compounds in cell suspension cultures of $T$. peruviana were responsible for the observed anti-oxidant activity. All together, these results give the first steps in metabolic behavior in cell suspension cultures of T. peruviana.
Key words: Plant metabolites, Anti-oxidant activity, Reactive Oxygen Species, Phenols, Plant cell suspension culture, Thevetia peruviana.

\section{RESUMEN}

Se establecieron cultivos en suspensión de la especie vegetal Thevetia peruviana en oscuridad, durante 19 días, para estudiar el comportamiento cinético de producción de biomasa, consumo de sustrato, producción de glicósidos cardiotónicos, polifenoles, especies reactivas de oxígeno y actividad antioxidante. Los resultados mostraron una alta producción de biomasa (18,80g PS/L), al igual que consumo total de sacarosa, a los 7 días de cultivo. Se observó un consumo preferencial de glucosa sobre fructosa durante todo el cultivo. La producción de glicósidos cardiotónicos intracelulares alcanzó valores de 2,58mg ED/g PS, al día 19. La mayor producción extracelular $(6,19 \mathrm{mg}$ ED/L), se alcanzó entre los días 2 y 7 . El mayor contenido de compuestos fenólicos extracelular fue de 80,61 $\pm 5,16 \mathrm{mg} \mathrm{GAE} / \mathrm{L}$, en el día 7. El contenido de compuestos fenólicos intracelulares incrementó a 2,76 $\pm 0,14 \mathrm{mg} \mathrm{AGE/gPF,} \mathrm{al} \mathrm{día} 7$ y se mantuvo 
constante, hasta el día 19. La producción de EROs, al día 7, puede estar relacionada con el consumo total de sacarosa y glucosa. El coeficiente de correlación producto-momento de Pearson ( $\rho$ ) indicó que los compuestos fenólicos en cultivos celulares en suspensión de $T$. peruviana eran los responsables de la actividad antioxidante observada. En conjunto, estos resultados brindan las primeras bases relacionadas al comportamiento metabólico de cultivos celulares en suspensión, de T. peruviana.

Palabras clave: Metabolitos de plantas, Actividad antioxidante, Especies reactivas de oxígeno, Fenoles, Cultivo de células vegetales en suspensión, Thevetia peruviana.

\section{INTRODUCTION}

In recent years, plant cell cultures have become an important platform for secondary metabolite production (Ochoa et al. 2016). Thevetia peruviana (Pers.) K.Schum. (Apocynaceae) also called "Lucky nut" is recognized for the presence of several biological active compounds. Among these compounds cardiac glycosides (Kohls et al. 2012) which are used during heart failure treatment stand out (Zibbu \& Batra, 2011). However, most studies with this plant species had been focused on the antimicrobial activity of plant extracts and their toxicity (Reddy, 2009; Gezahegn et al. 2015; Bhoyar \& Biradar, 2014; Rahman et al. 2014; Kareru et al. 2010a; 2010b; Hassan et al. 2011). Although the identification of other compounds and their respective activity has also been investigated (Tewtrakul et al. 2002; Amaringo et al. 2011; Miyagawa et al. 2009).

Polyphenols are an important family of plant metabolites with a powerful anti-oxidant activity derived from its free radical/reactive oxygen species (ROS) scavenging activity (Fang et al. 2002). ROS are extremely dangerous to living organisms including plants, as they can damage all major bio-polymers (i.e. lipids, proteins, nucleic acids) resulting in the organism dysfunction. In consequence plants have developed numerous ROS-scavenging systems to minimize the cytotoxic effects of ROS (Demidchik, 2014). One of the strategies to overcome an oxidative stress is the production of polyphenols and other non-enzymatic antioxidants such as ascorbic acid, glutathione, proline, polyamines, certain flavonoids and several secondary metabolites (Zhao et al. 2005).

Due to the importance of antioxidant molecules for the plants and as a biotechnology product, the production of phenolic compounds by cell suspension cultures of $T$. peruviana have been studied before. Arias et al. (2016) observed a detrimental effect on phenolic compounds production under different light wavelength; the highest phenolic content and anti-oxidant activity was obtain under darkness condition. However, to date there are no studies describing in detail the kinetic behavior of cell suspensions cultures of T. peruviana and their metabolite production. In addition to the phenolic compounds found in T. peruviana, the cell suspension cultures of this plant showed the ability to produce extracellular peruvoside (Arias et al. 2009), which is a type of cardiac glycoside with high potential in biomedical applications. Nonetheless, the kinetic behavior of the production of peruvoside is currently unknown.

Therefore, the aim of this work was to study the kinetics of biomass, cardiac glycosides, phenolic compounds and ROS production by cell suspension cultures of $T$. peruviana under darkness condition during 19 days. In addition, sugar consumption and anti-oxidant activity was also analyzed, in order to enhance our understanding of the metabolism of this promising in vitro culture.

\section{MATERIALS AND METHODS}

Plant material and cell suspension cultures. The protocol for establishment of the in vitro cultures of $T$. peruviana from pulp has already been described in detail (Arias et al. 2009). Briefly, fruits were initially disinfected using ethanol $(70 \% \mathrm{v} / \mathrm{v})$, sodium hypochlorite $(10 \% \mathrm{w} / \mathrm{v})$ and sterile distilled water. Next, fresh explants were extracted aseptically and sowed in solid Schenk and Hildebrandt (SH) medium supplemented with $30 \mathrm{~g} / \mathrm{L}$ sucrose, $2 \mathrm{mg} / \mathrm{L}$ of $2,4-\mathrm{D}$ and $0.5 \mathrm{mg} / \mathrm{L}$ of kinetin. Friable callus $(4 \mathrm{~g})$ were transfer to $250 \mathrm{~mL}$ Erlenmeyer flask with $\mathrm{SH}$ liquid medium. Cell suspension cultures were maintained at $25^{\circ} \mathrm{C}$, constant agitation (110rpm) and darkness condition. All cell suspension cultures used in the experiments were in exponential growth phase.

Study was carried out in $100 \mathrm{~mL}$ Erlenmeyer flask with $18 \mathrm{~mL}$ of cell suspension at the same maintenance conditions. Every 2-3 days during 19 days of culture, three Erlenmyer flasks were taken out to be analyzed according to the described below methods.

Cell growth determination. Cell growth was determined by dry weight (DW). Cell culture aliquots were subjected to vacuum filtration through a pre-dried $\left(60^{\circ} \mathrm{C}-24 \mathrm{~h}\right)$ filter paper Whatman 595 (Sigma-Aldrich Bogotá, Colombia). Next, the retained sample was washed 3 times with distilled water and dried in a convection oven until it reached constant weight after $24 \mathrm{~h}$ at $60^{\circ} \mathrm{C}$.

Sugar quantification. Extracellular sucrose, fructose and glucose concentration were analyzed using a Shimadzu Prominence High Pressure Liquid Chromatography (HPLC) system with a pumping system LC-20 CE coupled to a refractive index detector RID-10A and the Solution LC software was used (Shimadzu Scientific Instruments, Inc. 
(USA). Separation and quantification of sugars was carried out using a reverse phase amino column RP-NH2 NUCLEODUR 100-5 (Macherey-Nagel Inc. PA. USA.) and mobile phase acetonitrile/water (79:21 v/v ratio), with a flow $2 \mathrm{~mL} / \mathrm{min}$ and a sample size of $10 \mu \mathrm{L}$ at $35^{\circ} \mathrm{C}$.

Metabolite extraction and analysis. Cardiac glycosides production and phenolic content was determined from medium culture and cells, as follows: extracellular samples (cardiac glycosides, phenolic content and anti-oxidant activity) were prepared by microfiltration $(0.2 \mu \mathrm{m})$ of cells free medium. Intracellular cardiac glycoside samples were obtained from 100mg of fresh biomass collected by filtration and resuspended in $1 \mathrm{~mL}$ of ethanol $(96 \% \mathrm{v} / \mathrm{v})$. The cells were dispersed and lyzed in an ultrasound bath for 30 minutes $\left(40 \mathrm{KHz}-20^{\circ} \mathrm{C}\right)$. The remaining cells and cell debris were eliminated by centrifugation at $10000 \mathrm{rpm}$ for $10 \mathrm{~min}$ at $4^{\circ} \mathrm{C}$. Intracellular phenolic content and anti-oxidant activity samples were obtained from $100 \mathrm{mg}$ of fresh biomass collected by filtration and resuspended in $1 \mathrm{~mL}$ of phosphate buffer $(\mathrm{pH} \mathrm{4})$. Cells extracts (extra and intracellular) were stored at $-20^{\circ} \mathrm{C}$ until use.

Cardiac glycoside determination using HPLC analysis. Cardiac glycosides extracted were analyzed using a Shimadzu Prominence HPLC system with a pumping system LC- 20 CE coupled to a Diode Array Detector (SPD-20A) at 220nm, thermostated at $30^{\circ} \mathrm{C}$ with a Column Oven (CTO - 20A). Chromatographic data were collected and processed using the Solution LC software (Shimadzu Scientific Instruments, Inc. USA). The column used was a LiChrospher ${ }^{\circledR}$ 100RP-18 $(4 \times 250 \mathrm{~mm}, 5 \mu \mathrm{m})$. Solvents were acetonitrile/water $(79: 21$ $\mathrm{v} / \mathrm{v}$ ratio), flow rate was set to $1 \mathrm{~mL} / \mathrm{min}$ and the injection volume was $10 \mu \mathrm{L}$. For total cardiac glycosides quantification, the sum of the areas of the peaks detected at $220 \mathrm{~nm}$ with close retention time to the standards (Digoxin $-T_{R}$ : 9.431min and Peruvoside - $\mathrm{T}_{\mathrm{R}}$ : 10.944min) was calculated. Total cardiac glycosides were expressed as mg Digoxin Equivalents (DE)/L on the basis of a calibration curve prepared with commercial Digoxin (Sigma-Aldrich, USA).

Phenolic content. The phenolic content was determined by the adapted Folin-Ciocalteu method (Singleton \& Rossi, 1965). Cell extracts $(25 \mu \mathrm{L})$ were mixed with $70 \mu \mathrm{L}$ of FolinCiocalteu solution and $200 \mu \mathrm{L}$ of sodium carbonate solution $(7.1 \% \mathrm{w} / \mathrm{v})$. The resulting solution was brought to a final volume of $500 \mu \mathrm{L}$ with distilled water. This solution was stirred and stored at $25^{\circ} \mathrm{C}$ for $30 \mathrm{~min}$ in darkness, and the absorbance was measured at $760 \mathrm{~nm}$. The absorbance values were compared with the standard (Aqueous solutions of Gallic Acid) and the results were expressed as mg Equivalent Gallic Acid /g Dry Weight (mg GAE/DW) and mg Equivalent Gallic Acid/L (mg GAE/L) for intra and extracellular samples, respectively.
Antioxidant activity of cell extracts. Total antioxidant capacity was measured by ABTS method. This technique determines the capacity of a sample to trap the cationic radical ABTS and discolor the probe 2,2-azino-bis(3-ethylbenzothiazoline6-sulphonic) acid (ABTS). 20 $\mu \mathrm{L}$ of each extract were added to $1980 \mu \mathrm{L}$ of ABTS solution and after $30 \mathrm{~min}$ the absorbance at $732 \mathrm{~nm}$ was measured. The absorbance values were compared to the reference curve prepared with Trolox as a primary standard. The results were expressed in $\mu \mathrm{mol}$ of Trolox/gDW.

Reactive oxygen species (ROS) production. Generation of ROS during the cell growth was evaluated using 2',7'dichlorofluorescein diacetate (DCFDA), a ROS-sensitive dye. The reagent DCFDA, is a fluorogenic dye that measures hydroxyl, peroxyl and other ROS activity within the cell. After diffusion inside the cell, DCFDA is deacetylated by cellular esterases to a non-fluorescent compound, which is later oxidized by ROS into 2',7'dichlorofluorescein (DCF). DCF is a highly fluorescent compound which can be detected by fluorescence spectroscopy. The protocol employed was proposed by Martín-Romero et al. (2008) much less is known regarding the contribution of culture media to the oxidative stress of gametes during assisted reproductive techniques. This study measured the generation of ROS by culture media during IVF procedures and its effects on human oocytes. Commercially supplied culture media generated ROS at various rates, depending on the composition, whereas follicular fluid generated ROS at a much lower level. The incubation of cumuluslu2013oocyte complexes (COC and it is described below. Aliquots of $30 \mu \mathrm{L}$ of sample were warmed to $37^{\circ} \mathrm{C}$ before addition of $270 \mu \mathrm{L}$ of DCFDA $(40 \mu \mathrm{mol} / \mathrm{L})$ in phosphate buffer. The kinetics of fluorescence emission was measured at excitation and emission wavelengths of 490 and $530 \mathrm{~nm}$ respectively, for 3000 seconds. The rate of DCFDA oxidation was calculated from the slope of emission of fluorescence during the time interval. DCFDA oxidation rate can be assumed as an index of ROS production, i.e., higher oxidation rate indicates higher ROS production as indicated by several studies (Grzelak et al. 2001; Samhan-Arias et al. 2004).

Experiments on antioxidant activity (Phenols, ABTS and ROS) were performed in triplicate. The data are presented as the mean \pm the standard error. To establish significant differences between the samples One-Way ANOVA was made $(p<0.05)$. Pearson correlation coefficient was estimated to determine the relationship between two response variables; all the statistical analysis and coefficients were calculated using the Statgraphics Centurion V statistical package (Statgraphics, USA) for Windows. 


\section{RESULTS AND DISCUSSION}

Cell growth and substrate consumption. Cell suspension cultures of $T$. peruviana under darkness condition (Figure 1) showed a similar behavior than the reported in previous studies regarding to sugar uptake and growth (Arias et al. 2016). However, faster sucrose consumption, when compared to Arias et al. (2016), 7 days instead of 10 days, was due to higher inoculum size $(5.75 \mathrm{gDW} / \mathrm{L})$, which also slightly increased the final biomass concentration to $18.80 \mathrm{gDW} / \mathrm{L}$.
Sucrose concentration during culture decreased from 25 to $0.4 \mathrm{~g} / \mathrm{L}$ at day 7 . This fast consumption of sucrose is related to the metabolic use of sucrose by cells, which involves two different pathways. In the first pathway sucrose can be hydrolyzed to hexoses (fructose and glucose) by cell-wall invertases and then transported into cells through hexose transporters. While in the second pathway, sucrose can be directly imported into cells through sucrose transporters (Shiratake, 2007). In the case of glucose and fructose their concentration increased until day $2(1.9 \pm 0.03 \mathrm{~g} / \mathrm{l})$ and day $7(4.9 \pm 1.4 \mathrm{~g} / \mathrm{L})$, respectively, with higher accumulation of

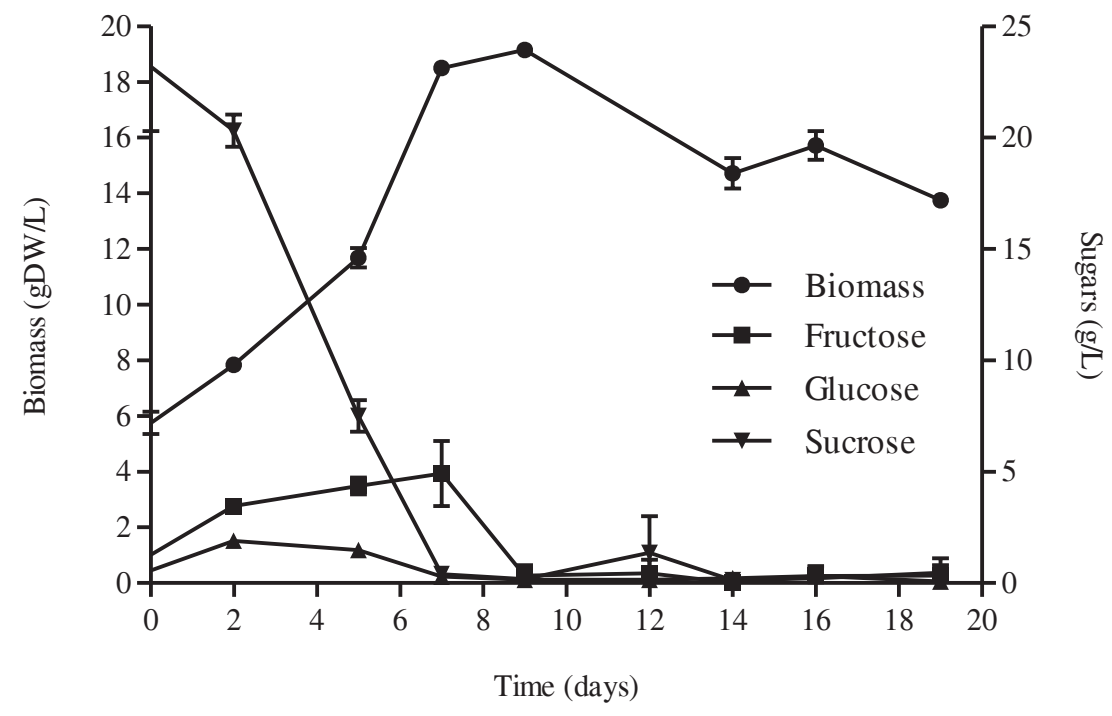

Figure 1. Cell growth and sugar uptake curves for cell suspension cultures of T. peruviana under darkness condition. Results are presented as average $\pm \operatorname{SD}(n=3)$.

fructose. Then by day 7 and day 9 the concentration of both sugars were highly reduced.

Accumulation of fructose in the extracelullar medium during cell growth has been reported for transgenic rice (Trexler et al. 2002), Daucus carota (Krook et al. 2000) and other plant species cultured in vitro, similarly as observed in this study for $T$. peruviana. In addition, there was a preferential consumption of glucose over fructose during all culture as indicated by the fast consumption of glucose in figure 1 . Likewise, preferential use of glucose over fructose had also been reported for several plant species were a better growth in the presence of glucose was observed (Fowler, 1982; Mukherjee et al. 2000; Krook et al. 2000; Shinde et al. 2009).

Cardiac glycosides production. Figure 2 presents the kinetics of extra and intracellular cardiac glycosides production over 19 days of culture. Cardiac glycosides in cell suspensions cultures of T. peruviana showed a production associated with both primary (day 0 - day 9 ) and secondary (day 9 - day 19) metabolism. Intracellular production of cardiac glycosides started with $0.54 \mathrm{mg}$ Digoxin Equivalent (DE)/gDW at day 0 and reached $2.58 \mathrm{mgDE} / \mathrm{gDW}$ at day 19 . The highest extracellular production was reached between day 2 and 7 (6.19mgDE/L), then it was observed a continue decrease until day 19 (0.91mgDE/L). Extracellular cardiac glycoside content was comparable with the reported by Arias et al. (2009) taking into account that they worked with elicited suspension cultures of $T$. peruviana, reaching peruvoside production of $8.93 \mathrm{mg} / \mathrm{L}$ in the presence of $100 \mathrm{mg} / \mathrm{L}$ of Methyl Jasmonate.

Our study is the first that has measured the intracellular production of cardiac glycoside from cell suspension culture of T. peruviana. while a previous study only reported extracellular production of peruvoside (Arias et al. 2009). 


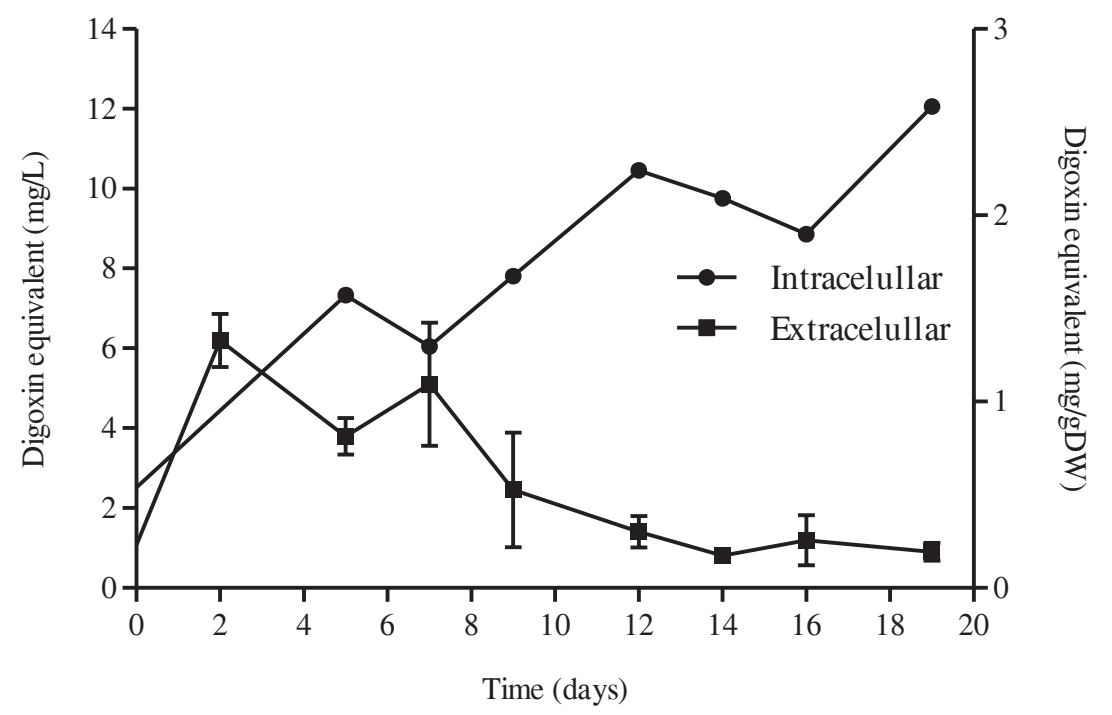

Figure 2. Cardiac glycoside production expressed as mg Digoxin equivalent/L (Extracellular) and mg Digoxin equivalent/gDW (Intracellular) in cell suspension cultures of $T$. peruviana under darkness condition. Results are presented as average \pm SD $(n=3)$.

Interestingly, the values for cardiac glycosides obtained here are higher than the reported values obtained in other in vitro species of Thevetia. For example, callus cultures of $T$. neriifolia and $T$. thevetioides reported values of the cardiac glycoside Thevetin B, of 0.085 and $0.047 \mathrm{mg} / \mathrm{gDW}$, respectively. Additionally, when all the cardiac glycosides for $T$. neriifolia and T. thevetioides callus (thevetin B, digitoxigenin, peruvoside and neriifolin) are added, the total cardiac glycosides value reached 0.145 and $0.123 \mathrm{mg} / \mathrm{gDW}$, respectively (Taha et al. 2010). In comparison our study showed an increase of almost 18 times $(2.58 \mathrm{mg} / \mathrm{gDW})$ of cardiac glycosides, highlighting the potential of the cell suspension cultures in the production of these molecules.

Around 15-18 types of cardiac glycosides are present in different parts of the plants (Nesy \& Mathew, 2015). Kohls et al. (2012), identified six Thevetia cardiac glycosides isolated from the seeds using LC- ESI-MS(/MS) analysis among which was Thevetin A, B, C and Digitoxin. Nesy \& Mathew (2015), obtained a profile of cardiac glycosides presents in leaf extracts, with a good amount of peruvoside in single or in two isomeric forms. There have been few studies which identify the exact cardiac glycoside metabolites produced in in vitro cultures of $T$. peruviana. Taha et al. (2010; 2011) identified cardiac glycosides (i.e. digitoxigenin and thevetin B) in callus from immature seeds of two Thevetia species (T. neriifolia and T. thevetioides).

Phenolic content and antioxidant capacity. The extra/ intracellular phenolic content and antioxidant activity (ABTS value) of cell suspension cultures of T.peruviana are presented in figure 3. The results showed a fast production stage from day 0 to 7 , for both extra and intracellular phenols. The highest extracellular phenolic content was $80.61 \pm 5.16 \mathrm{mgGAE} / \mathrm{L}$ at day 7 , followed by a decline around $50 \mathrm{mgGAE} / \mathrm{L}$ during the rest of the culture (Figure 3a).

Intracellular phenolic content increased to $2.76 \pm$ $0.14 \mathrm{mgGAE} / \mathrm{gFW}$ at day 7 and remained constant until day 19 (Figure 3b). If we express our data in base of dry weight, assuming $90 \%$ of cell humidity; production of polyphenols by cell suspensions cultures of $T$. peruviana in this work was 10 times higher (27.6 $\mathrm{mgGAE} / \mathrm{gDW}$ ) in comparison to the reported by the plants cultivated in field $(2.14 \mathrm{mgGAE} / \mathrm{g}$ dry leaf) (Zibbu \& Batra, 2011), in vitro callus and Methyl Jasmonate elicited callus, 0.95 and $2.8 \mathrm{mgGAE} / \mathrm{gDW}$, respectively (Rincón et al. 2016). The highest polyphenol content reported until now from T. peruviana was $33.59 \mathrm{mg}$ $\mathrm{GAE} / \mathrm{gDW}$ obtained from fruit methanol extracts (Dixit et al. 2015). However, it is important to note that the difference observed in phenolic content could be related due to the extraction processes used or the type of culture being investigated.

Correlations between phenolic content and ABTS activity extra/intracellular were calculated. The values in both case were positives and close to the unity (value $\rho$ ), $\rho=0.970$ and $\rho=0.973$, for extra and intracellular respectively. This means that there is a high correlation between the two variables. Therefore, the antioxidant activity is an expression of the 

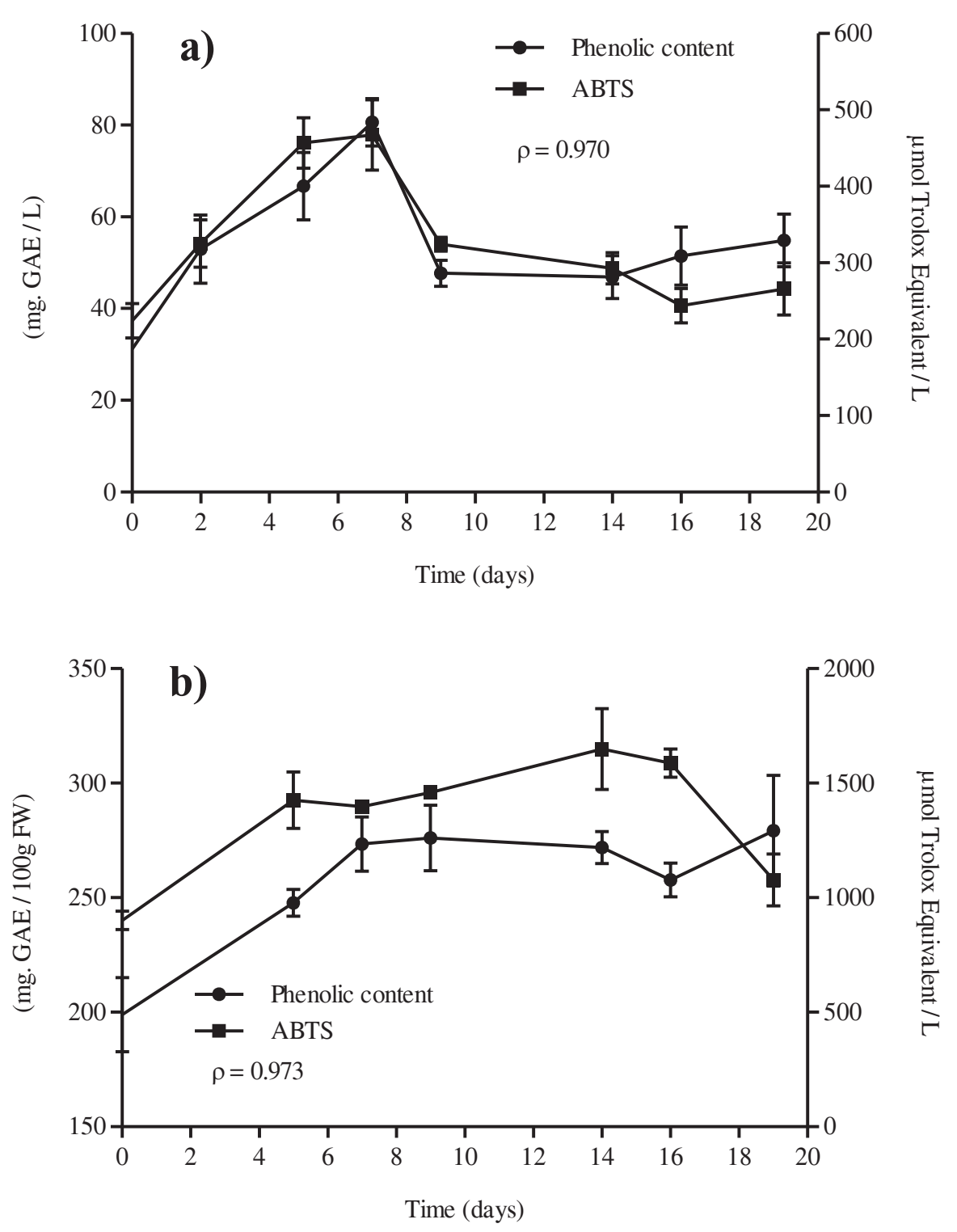

Figure 3. Extracellular: (a) and intracellular, (b) total phenolic content and 2,2'-azino-bis (3-ethyl benzothiazoline-6-sulphonic) acid (ABTS) capacity of cell suspension cultures of T. peruviana under darkness condition. Pearson Product-Moment Correlation Coefficient $(\rho)$. Results are presented as average $\pm \operatorname{SD}(n=3)$.

phenolic content of the evaluated samples, indicating that the phenolic compounds in cell suspension cultures of $T$. peruviana were largely responsible for the observed antioxidant activity. Similarly, this correlation had been reported for other plant cell cultures. For instance, Lim et al. (2013) revealed that there was a positive correlation $(\rho=0.961)$ between the total phenolic content with antioxidant activity for cell suspension cultures of Orthosiphon stamineus; this correlation value was similar to the calculated for this work.
Reactive oxygen species (ROS) production. The fluorescent dye DCFDA is sensitive to a wide range of ROS, and it has been previously used to monitor the generation of ROS in buffers (Grzelak et al. 2001; Martín-Romero et al. 2008) and in cell cultures (Martín-Romero et al. 2002; Samhan-Arias et al. 2004). In this study the oxidation rate of DCFDA during cell suspension growth of $T$. peruviana cells was analyzed in both, intracellular and extracellular extracts. This approach provided an index of ROS generation within the cells as well as in the surroundings during cell growth. 
Intracellular ROS rate production (Figure 4) in T. peruviana is almost constant during growth. However, intracellular ROS production might not be a reliable indication of the entire ROS been produce because the reactive species might be migrating to the extracellular medium. Consequently, the entire ROS production will be determined mainly by the content in the extracellular fluid. In addition, it has been shown that extracellular oxidation rates of different ROSsensitive dyes are significantly higher than those measured within the intracellular compartment (Burton et al. 2002; Martín-Romero et al. 2008). However, these data should not be understood as a higher rate of total ROS generation in the extracellular fluid. The difference in the dye oxidation rate in both sections can be explained in terms of the lack of antioxidants in the extracellular fluid, yielding a higher oxidation rate of the dye (Martín-Romero et al. 2008).
Extracellular ROS production over cultivation time showed a rapid increase between day 5 and day 7 followed by an exponential decrease. This behavior could be related to sucrose and glucose total consumption at day 7 . The depletion of sucrose could generates a stress condition to the cells (Couée et al. 2006), associated with a decrease in ADP regeneration rate (Brouquisse et al. 1991), and reduced electron transfer triggering an overproduction of ROS (Braidot et al. 1999).

This study showed an increased production of phenolic compounds (intra and extracellular) with anti-oxidant activity acting as a non-enzymatic response to the stress condition during the first 7 days. This behavior can be related to the ROS production observed during the same time frame. It is important to note that our study is the first that has measured

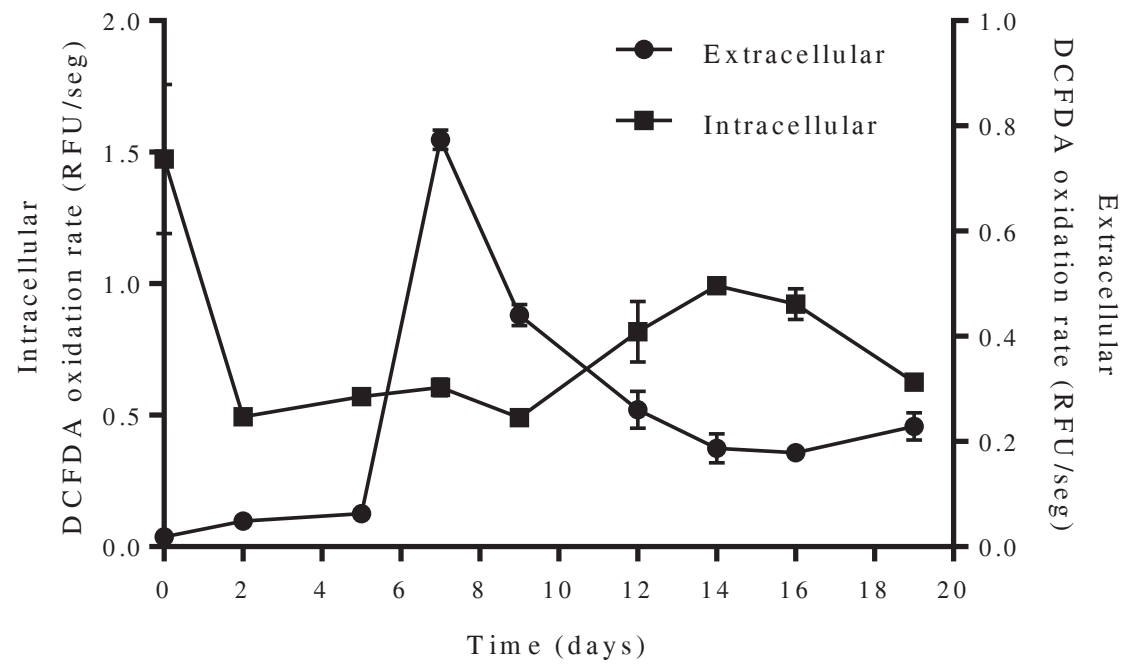

Figure 4. Extra and intracellular production of reactive oxygen species (ROS) in cell suspension cultures of T. peruviana under darkness condition expressed as 2',7'dichlorofluorescein diacetate oxidation rate in Relative Fluorescence Units (RFU)/seg. Results are presented as average $\pm \mathrm{SD}(\mathrm{n}=3)$.

ROS production over time and at the same time correlated this process with phenol compounds in the cell suspension cultures of $T$. peruviana. Finally, this work contributes with the first steps in the elucidation of the non-enzymatic response to ROS production and the metabolic behavior of cell suspension cultures of $T$. peruviana, which will provide the bases for the optimization in the production of secondary metabolites of high added value at shake flask scale and subsequent scaling.

Further studies should be focused on the elucidation and structural identification of produced phenolic and cardiotonic compounds as well as the evaluation of the biological activity of these metabolites.

Acknowledgments: The authors are grateful to the Facultad de Ciencias of Universidad Nacional de Colombia, Medellín, and Colciencias for the scholarship granted to Juan Pablo Arias. Conflicts of Interest: The manuscript was prepared and reviewed with the participation of all authors, who declare that there is no conflict of interest that jeopardizes the validity of the presented results. Financing: This study was funded by the Facultad de Ciencias of Universidad Nacional de Colombia, Medellín. 


\section{BIBLIOGRAPHY}

1. AMARINGO, F.V.; HORMANZA, A.; ARIAS, M. 2011. Thevetin B : Glicósido cardiotónico predominante en Thevetia peruviana. Scientia et Technica. 49:298-303.

2. ARIAS, J.P.; ZAPATA, K.; ROJANO, B.; ARIAS, M. 2016. Effect of light wavelength on cell growth, content of phenolic compounds and antioxidant activity in cell suspension cultures of Thevetia peruviana. J. Photochemistry \& Photobiology, B: Biology 163:87-91.

3. ARIAS, M.; ANGARITA, M.J.; RESTREPO, J.M.; CAICEDO, L.M.; PEREA, M. 2009. Elicitation with methyljasmonate stimulates peruvoside production in cell suspension cultures of Thevetia peruviana. In Vitro Cellular \& Developmental Biology - Plant. 46(3):233-338.

4. BHOYAR, S.; BIRADAR, S.D. 2014. Antibacterial activity of root extract of Thevetia peruviana (Pers.) Shum. Int. Res. J. Pharmacy. 5(6):468-470.

5. BRAIDOT, E.; PETRUSSA, E.; VIANELLO, A.; MACRÍ, F. 1999. Hydrogen peroxide generation by higher plant mitochondria oxidizing complex I -or complex Il substrates." FEBS Letters. 45 (3):347-350.

6. BROUQUISSE, R.; JAMES, F.; RAYMOND, P.; PRADET, A. 1991. Study of glucose starvation in excised maize root tips. Plant Physiology. 96:619-626.

7. BURTON, G.J.; HEMPSTOCK, J.; JAUINIAUX, E. 2002. Oxygen, early embryonic metabolism and free radical-mediated embryopathies. Reproductive Biomedicine Online. 6(1):84-96.

8. COUÉE, I.; SULMON, C.; GOUESBET, G.; AMRANI, E.A. 2006. Involvement of soluble sugars in reactive oxygen species balance and responses to oxidative stress in Plants." J. Experimental Botany. 57(3):449-459.

9. DEMIDCHIK, V. 2014. Mechanisms of oxidative stress in plants: From classical chemistry to cell biology. Environmental and Experimental Botany 109: 212228.

10. DIXIT, A.; SINGH, H.; SHARMA, R.A.; SHARMA, A. 2015. Estimation of antioxidant and antibacterial activity of crude extracts of Thevetia peruviana (Pers.)
K. Schum. Int. J. Pharmacy and Pharmaceutical Sciences. 7(2):55-59.

11. FANG, Y.-Z.; YANG, S.; WU, G. 2002. Free radicals, antioxidants, and nutrition. Nutrition. 18(10):872879.

12. FOWLER, M.W. 1982. Substrate utilisation by plantcell cultures. J. Chemical Technology and Biotechnology. 32(1):338-346.

13. GEZAHEGN, Z.; AKHTAR, M.S.; WOYESSA, D.; TARIKU, Y. 2015. Antibacterial potential of Thevetia peruviana leaf extracts against food associated bacterial pathogens. J. Coastal Life Medicine. 3(2):150-157.

14. GRZELAK, A.; RYCHLIK, B.; BARTOSZ, G. 2001. Lightdependent generation of reactive oxygen species in cell culture media. Free Radical Biology \& Medicine. 30(12):1418-1425.

15. HASSAN, M.M.; SAHA, A.K.; KHAN, S.A.; ISLAM, A.; MAHABUB-UZ-ZAMAN, M.; AHMED, S.S.U. 2011. Studies on the antidiarrhoeal, antimicrobial and cytotoxic activities of ethanol-extracted leaves of Yellow Oleander (Thevetia Peruviana). Open Veterinary J. 1:28-31.

16. KARERU, P.G.; KERIKO, J.M.; KENJI, G.M.; GACHANJA, A.N. 2010a. Anti-termite and antimicrobial properties of paint made from Thevetia peruviana (Pers.) Schum. oil extract. African J. Pharmacy and Pharmacology. 4(2):87-89.

17. KARERU, P.G.; KERIKO, J.M.; KENJI, G.M.; THIONG'O, G.T.; GACHANJA, A.N.; MUKIIRA, H.N. 2010b. Antimicrobial activities of skincare preparations from plant extracts. African J. Traditional, Complementary and Alternative Medicines. 7(3):214-218.

18. KOHLS, S.; SCHOLZ-BÖTTCHER, B.M.; TESKE, J.; ZARK, P.; RULLKÖTTER, J. 2012. Cardiac glycosides from Yellow Oleander (Thevetia peruviana) seeds. Phytochemistry. 75:114-127.

19. KROOK, J.; VREUGDENHIL, D.; VAN DER PLAS, L.H.W. 2000. Uptake and phosphorylation of glucose and fructose in Daucus carota cell suspensions are differently regulated. Plant Physiology and Biochemistry. 38(7-8):603-612. 
20. LIM, F.L.; YAM, M.F.; ASMAWI, M.Z.; CHAN, L.-K. 2013. Elicitation of Orthosiphon stamineus cell suspension culture for enhancement of phenolic compounds biosynthesis and antioxidant activity. Industrial Crops and Products. 50:436-442.

21. MARTÍN-ROMERO, F.J.; GARCÍA-MARTÍN, E.; GUTIÉRREZ-MERINO, C. 2002. Inhibition of oxidative stress produced by plasma membrane NADH oxidase delays low-potassium-induced apoptosis of cerebellar granule cells. J. Neurochemistry. 82(3):705-715.

22. MARTÍN-ROMERO, F.J.; MIGUEL-LASOBRAS, E.M.; DOMÍNGUEZ-ARROYO, J.A.; GONZÁLEZCARRERA, E.; ÁLVAREZ, I.S. 2008. Contribution of culture media to oxidative stress and its effect on human oocytes. Reproductive BioMedicine Online. 17(5):652-661.

23. MIYAGAWA, T.; OHTSUKI, T.; KOYANO, T.; KOWITHAYAKORN, T.; ISHIBASHI, M. 2009. Cardenolide glycosides of Thevetia peruviana and triterpenoid saponins of Sapindus emarginatus as Trail Resistance-Overcoming compounds. J. Natural Products. 72:1507-1511.

24. MUKHERJEE, S.; GHOSH, B.; JHA, S. 2000. Establishment of forskolin yielding transformed cell suspension cultures of Coleus forskohlii as controlled by different factors. J. Biotechnology. 76(1):73-81.

25. NESY, E.A.; MATHEW, L. 2015. HPTLC Profiling on cardiac glycosides of Thevetia peruviana leaf extracts of three morphovariant plants grown in Kerala, India. Int. J. Pharmacy and Pharmaceutical Sciences. 7(6):191-195.

26. OCHOA-VILLAREAL, M,; HOWAT, S.; HONG, S.; JANG, M.O.; JIN, Y.W.; LEE, E.K.; LOAKE, G.J. 2016. Plant cell culture strategies for the production of natural productus. BMB Reports. 49(3):149-158.

27. RAHMAN, N.; MAHMOOD, R.; RAHMAN, H.; HARIS, M. 2014. Spectrophotometric screening of potent bactericidal property of Thevetia peruviana Schum. Leaf and fruit rind extracts on clinical and plant pathogens. Int. Applied Sciences and Biotechnology. 2(4):451-459.

28. REDDY, B. 2009. Antimicrobial activity of Thevetia peruviana (Pers.) K. Schum. and Nerium indicum Linn. The Internet J. Pharmacology. 8(2).
29. RINCÓN-PÉREZ, J.; RODRÍGUEZ-HERNÁNDEZ, L.; RUÍZ-VALDIVIEZO, V.M.; ABUD-ARCHILA, M.; LUJÁN-HIDALGO, M.C.; RUIZ-LAU, N.; GONZÁLES-MENDOZA, D.; GUTIÉRREZMICELI, F.A. 2016. "Fatty ccids profile, phenolic compounds and antioxidant aapacity in elicited callus of Thevetia peruviana (Pers .) K . Schum. J. Oleo Science 318(4):311-318.

30. SAMHAN-ARIAS, A.K.; MARTÍN-ROMERO, F.J.; GUTIÉRREZ-MERINO, C. 2004. Kaempferol blocks oxidative stress in cerebellar granule cells and reveals a key role for reactive oxygen species production at the plasma membrane in the commitment to apoptosis. Free Radical Biology $\varepsilon$ Medicine. 37(1):48-61.

31. SHINDE, A.N.; MALPATHAK, N.; FULZELE, D.P. 2009. Studied enhancement strategies for phytoestrogens production in shake flasks by suspension culture of Psoralea corylifolia. Bioresource Technology 100(5):1833-1839.

32. SHIRATAKE, K. 2007. Genetics of sucrose transporter in plants. Genes, Genomes and Genomics. 1:73-80.

33. SINGLETON, V.L.; ROSSI, J.A.Jr. 1965. Colorimetric of total phenolics with phosphomolybdicphosptungstic acid reagents. Amer. J. Enol. Viticult. 16:144-158.

34. TAHA, H.S.; FARAG, K.A.; SHAMS, N.S.; ABDEL-AZIM, N.S.; SEIF EL-NASR, M.M. 2011. In vivo and in vitro studies on Thevetia species growing in Egypt II. Establishment of in vitro tissue culture system and production of cardiac glycosides. J. American Science. 7(3):1-2.

35. TAHA, H.S.; FARAG, K.A.; SHAMS, N.S.; ABDEL-AZIM, N.S.; HANNA, G.A.; SEIF EL-NASR, M.M. 2010. In vivo and in vitro studies on Thevetia species growing in Egypt I: Isolation, Identification, and Quantification of cardiac glycosides in in vivo and in vitro cultures of immature seeds. J. American Science. 6(11):390-395.

36. TEWTRAKUL, S.; NAKAMURA, N.; HATTORI, M.; FUJIWARA, T.; TANOMJIT, S. 2002. Flavanone and flavonol glycosides from the leaves of Thevetia peruviana and their HIV-1 reverse transcriptase and HIV-1 integrase inhibitory activities. Chemical \& Pharmaceutical Bulletin. 50(5):630-635. 
37. TREXLER, M.M.; McDONALD, K.A.; JACKMAN, A.P. 2002. Bioreactor production of human alpha(1)Antitrypsin using metabolically regulated plant cell cultures. Biotechnology Progress. 18(3):501-508.

38. ZHAO, J.; DAVIS, L.C.; VERPOORTE, R. 2005. Elicitor signal transduction leading to production of plant secondary metabolites. Biotechnology Advances. 23(4):283-333.
39. ZIBBU, G.; BATRA, A. 2011. Thevetia peruviana (Pers.) Schum.: A Plant with enormous therapeutic potential. J. Pharmacy Research. 4(12):44614464.

Recibido: Junio 5 de 2017

Aceptado: Noviembre 22 de 2017

Cómo citar:

Arias, J.P.; Zapata, K.; Rojano, B.; Peñuela, M.; Arias, M. 2017. Cardiac glycosides, phenolic compounds and antioxidant activity from plant cell suspension cultures of Thevetia peruviana. Rev. U.D.C.A Act. \& Div. Cient. 20(2): 353-362. 